\title{
RANGE EXTENSION OF THE BRAZILIAN DWARF BOA Tropidophis paucisquamis (MÜLLER, 1901) (SERPENTES, TROPIDOPHIIDAE) AND FIRST RECORD IN THE STATE OF MINAS GERAIS, BRAZIL
}

\author{
Leandro de Avelar Oliveira ${ }^{1^{*}}$, Pedro Carvalho Rocha ${ }^{1,2}$, Jonas Ferrari Morais ${ }^{1,2}$ \& Renato \\ Neves Feio ${ }^{1,2}$
}

\begin{abstract}
${ }^{1}$ Universidade Federal de Viçosa, Departamento de Biologia Animal, Museu de Zoologia João Moojen, Laboratório de Herpetologia, Vila Gianetti, 32, CEP 36570-900, Viçosa, MG, Brazil.

${ }^{2}$ Universidade Federal de Viçosa, Departamento de Biologia Animal, Programa de Pós-Graduação em Biologia Animal, Museu de Zoologia João Moojen, Laboratório de Herpetologia, Vila Gianetti, 32, CEP 36570-900, Viçosa, MG, Brazil.

E-mails: avelarleandrocaps@gmail.com (*corresponding author); p.rocha1990@gmail.com; morais.jonasf@gmail.com; rfeio@ufv.br
\end{abstract}

\begin{abstract}
Tropidophis paucisquamis is a rare small-sized snake, endemic to the Atlantic Forest and strongly associated with coastal mountain ranges with elevations above $500 \mathrm{~m}$ a.s.l. In this work, we provide the first record of this species in the state of Minas Gerais, Brazil, being the most continental record for the species and extending its distribution approximately $180 \mathrm{~km}$ from the closest known localities, and $465 \mathrm{~km}$ from its type locality. This finding fills a distribution gap between the states of Rio de Janeiro and Espírito Santo, Brazil, and expands our understanding about T. paucisquamis geographic distribution.
\end{abstract}

Keywords: Atlantic Forest; defensive behavior; Serra do Brigadeiro; snake; Squamata.

The Brazilian dwarf boa, Tropidophis paucisquamis (Müller, 1901) is a rare Tropidophiidae, characterized by aglyphous dentition, rows of dark spots around their bodies and diminutive size, about $150 \mathrm{~mm}$ (Hedges 2002, Freitas 2003, Barbo et al. 2011, Curcio et al. 2012). The species is endemic to the Brazilian Atlantic Forest (sensu IBGE \& MMA 2004) and strongly associated with coastal mountain ranges with elevation above 500 $m$ a.s.l. (Curcio et al. 2012). Brazilian dwarf boas often present arboreal habits and nocturnal activity (Barbo et al. 2011). So far, this species has been known from three mountain complexes restricted to the states of Espírito Santo, Rio de Janeiro, São Paulo and Paraná, in southeastern and southern Brazil: 1) Serra do Mar; 2) Serra da Mantiqueira; and 3) Planalto Paulistano-Paranaense (Capela et al. 2017). Herein, we report a new locality for $T$. paucisquamis, the first in the state of Minas Gerais and the most continental record for the species, in an area belonging to Serra da Mantiqueira mountain range.

On 06 November 2017 (air temperature $16^{\circ} \mathrm{C}$ ), we found a specimen of T. paucisquamis on the ground, amongst the marginal vegetation of a temporary pond commonly known as Lagoa das Bromélias, at Parque Estadual da Serra do Brigadeiro (Serra do Brigadeiro State Park; PESB), municipality of Ervália, state of Minas Gerais, Brazil (Figure 1; $20^{\circ} 53$ '30" S, 42 $31^{\prime} 41^{\prime \prime} \mathrm{W}$, datum WGS84; $1227 \mathrm{~m}$ a.s.l.). The individual was a male (Figure 2a), 296 $\mathrm{mm}$ snout-vent length, $45 \mathrm{~mm}$ caudal length, 168 


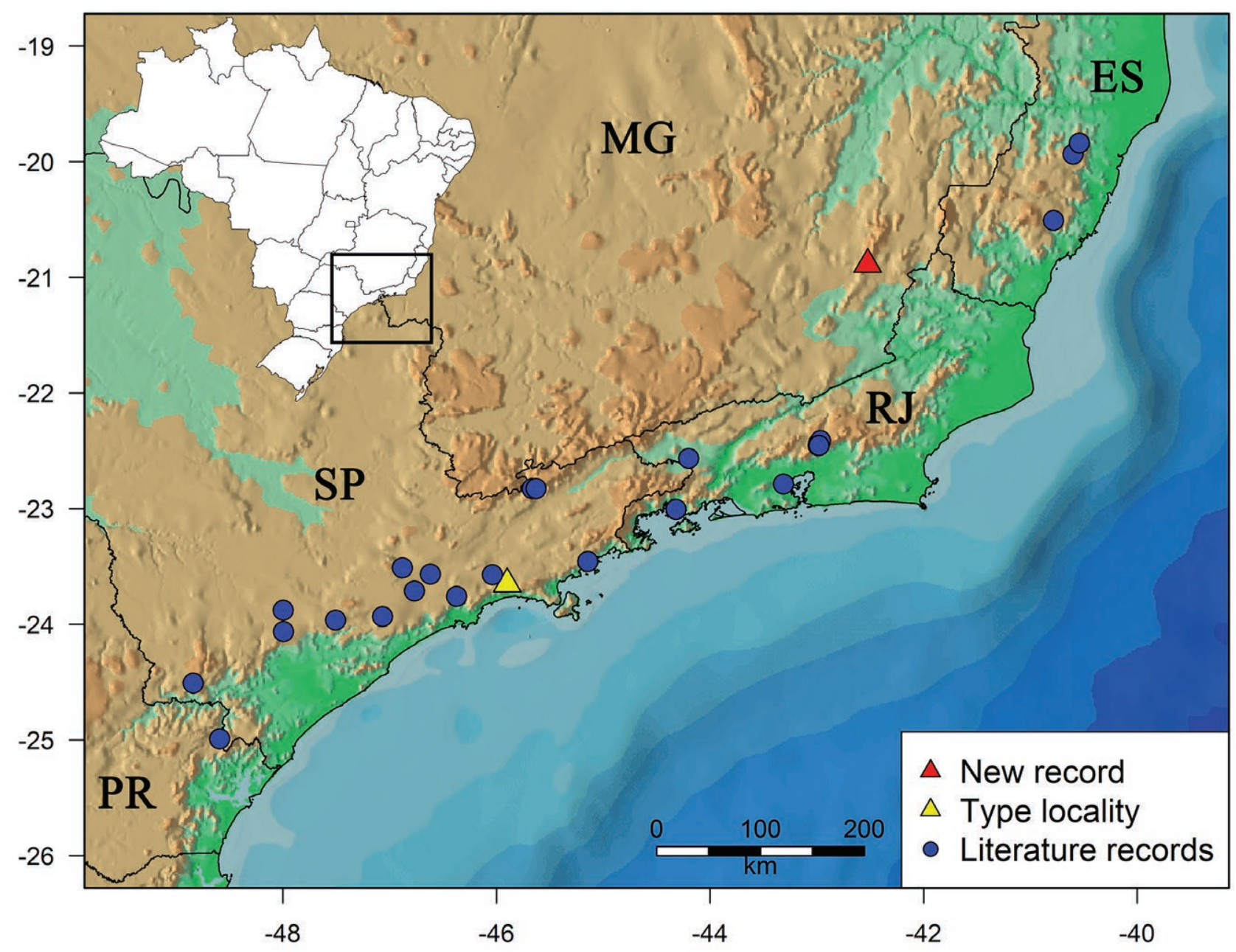

Figure 1. Previously known locality records and the new record of Tropidophis paucisquamis (Serpentes, Tropidophiidae). Inset map: Brazil, detailing the area of the main map. ES = Espírito Santo; MG = Minas Gerais; PR = Paraná; RJ = Rio de Janeiro; SP = São Paulo. See Table 1 for coordinates and record references.

ventral scales, 23 dorsal scales at midbody, and lacking interparietal scales, characters within the know range of T. paucisquamis (Curcio et al. 2012).

Whilst the specimen was manipulated and photographed, it displayed the defensive behaviors of coiling the body and hiding the head (Figure 2b), well reported for the species (e.g., Antunes \& Haddad 2009, Barbo et al. 2011, Tanaka et al. 2018). The specimen was euthanized with an injection of $10 \%$ lidocaine, fixed in $10 \%$ formalin, preserved in $70 \%$ ethanol and is currently housed at the herpetological collection of the Museu de Zoologia João Moojen, Universidade Federal de Viçosa, state of Minas Gerais, Brazil (voucher MZUFV 2495). In addition, tissue samples were collected and will be integrated into the tissue collection of Universidade Federal do Mato Grosso do Sul.
To provide an updated distribution map for T. paucisquamis, we made a search of records of this species in the scientific literature, using the terms "Tropidophis paucisquamis", "distribution" and "range extension" as keywords in the electronic databases Google Schoolar and SciELO. Additionally, we searched for records in all volumes of the journal Herpetological Review, which traditionally publishes distribution records. Searches were made between April and May 2018.

From the papers found, eight presented geographical coordinates and three presented distribution maps of the species, which were used as references to generate the map of this work (Amaral 1930, Carvalho 1951, LevandeiraGonçalves et al. 2007, Forlani et al. 2010, Salles \& Silva-Soares 2010, Curcio et al. 2012, Capela et al. 2017, Tanaka et al. 2018). During this search, 

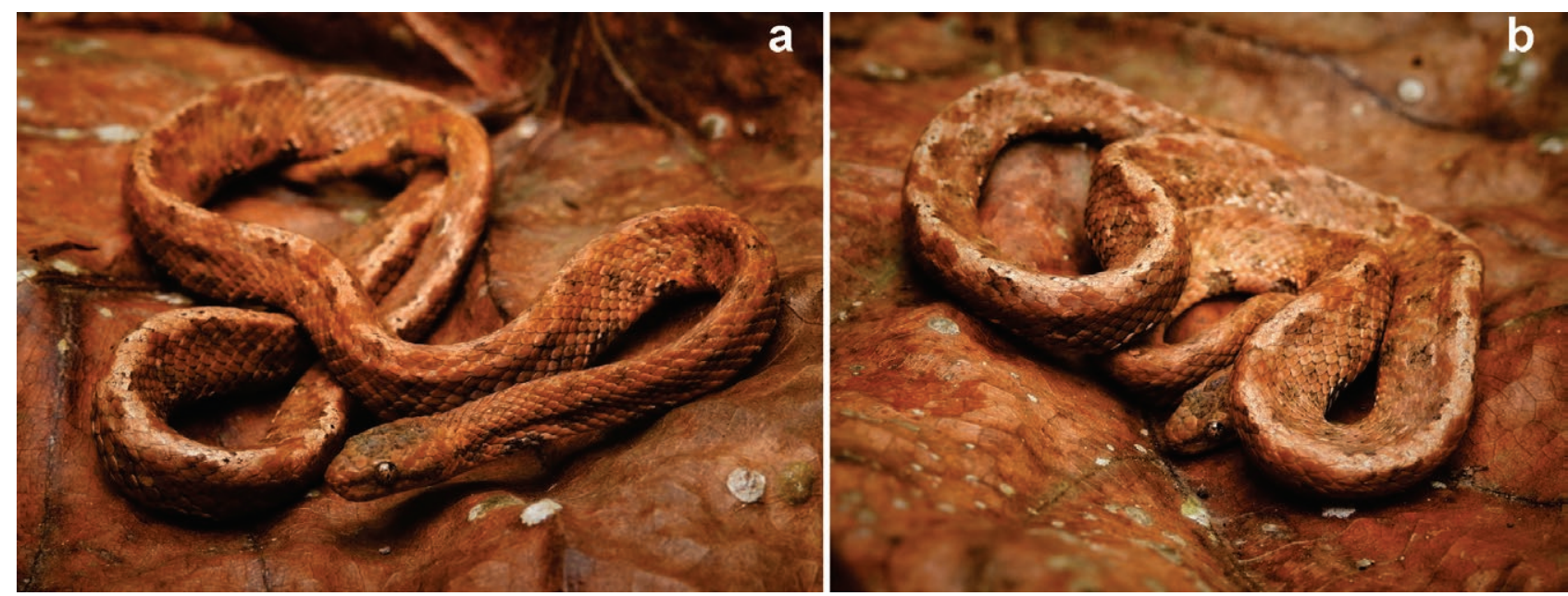

Figure 2. (a) Individual of Tropidophis paucisquamis (Serpentes, Tropidophiidae) found at Parque Estadual da Serra do Brigadeiro, municipality of Ervália, state of Minas Gerais, southeastern Brazil. (b) Same individual exhibiting defensive behaviour of head hiding. Photos by Leandro de Avelar Oliveira.

we found some incoherencies among provided coordinates and their respective localities (e.g., Curcio et al. 2012: provided coordinates that fall into a neighbor municipality instead of the one mentioned in the text). In such cases, we updated the coordinates using the centroid of the municipality as a proxy for the species record. When the authors provided specific localities for a record, such as protected areas, we used the coordinates of such specific places instead of the centroid of the municipality (Figure 1; Table 1).

Our record extends the distribution of $T$. paucisquamis about $465 \mathrm{~km}$ from its type locality (municipality of Salesópolis, state of São Paulo), and is the westernmost locality of occurrence for this species, approximately $176 \mathrm{~km} \mathrm{NE}$ of municipality of Teresópolis (state of Rio de Janeiro) and $180 \mathrm{~km}$ SW of Araguaia (state of Espírito Santo),

Table 1. Localities and coordinates from this study and the literature review of Tropidophis paucisquamis (Serpentes, Tropidophiidae) occurrence in Brazil.

\begin{tabular}{|c|c|c|c|c|c|}
\hline State & Municipality & Locality & Latitude & Longitude & Reference \\
\hline Minas Gerais & Ervália & $\begin{array}{l}\text { Parque Estadual Serra } \\
\text { do Brigadeiro* }\end{array}$ & -20.8868 & -42.5243 & This study \\
\hline Espírito Santo & Araguaia & - & -20.50 & -40.78 & $\begin{array}{l}\text { Curcio et al. } \\
\qquad(2012)\end{array}$ \\
\hline Espírito Santo & Santa Teresa & - & -19.93 & -40.60 & $\begin{array}{l}\text { Curcio et al. } \\
\qquad(2012)\end{array}$ \\
\hline Espírito Santo & Santa Teresa & $\begin{array}{l}\text { Reserva Biológica } \\
\text { Augusto Ruschi }\end{array}$ & -19.836 & -40.540 & $\begin{array}{l}\text { Curcio et al. } \\
\qquad(2012)\end{array}$ \\
\hline Rio de Janeiro & Angra dos Reis & Floresta & -23.006 & -44.318 & $\begin{array}{l}\text { Carvalho } \\
\text { (1951) }\end{array}$ \\
\hline Rio de Janeiro & Barra Mansa & Cotiara & -22.566 & -44.200 & $\begin{array}{l}\text { Curcio et al. } \\
\text { (2012) }\end{array}$ \\
\hline Rio de Janeiro & Duque de Caxias & - & -22.78 & -43.31 & $\begin{array}{l}\text { Salles \& Silva- } \\
\text { Soares (2010) }\end{array}$ \\
\hline
\end{tabular}

Table 1. Continued on next page... 
Table 1....Continued

\begin{tabular}{|c|c|c|c|c|c|}
\hline State & Municipality & Locality & Latitude & Longitude & Reference \\
\hline Rio de Janeiro & Teresópolis & $\begin{array}{c}\text { Parque Nacional Serra } \\
\text { dos Órgãos }\end{array}$ & -22.433 & -42.983 & $\begin{array}{c}\text { Levandeira- } \\
\text { Gonçalves et al. } \\
\text { (2007) }\end{array}$ \\
\hline Rio de Janeiro & Teresópolis & - & -22.41 & -42.96 & $\begin{array}{c}\text { Curcio et al. } \\
\text { (2012) }\end{array}$ \\
\hline Rio de Janeiro & Teresópolis & Alto do Soberbo & -22.454 & -42.989 & $\begin{array}{l}\text { Curcio et al. } \\
\qquad(2012)\end{array}$ \\
\hline Rio de Janeiro & Teresópolis & Represa Guinle & -22.454 & -42.980 & $\begin{array}{l}\text { Curcio et al. } \\
\qquad \text { (2012) }\end{array}$ \\
\hline São Paulo & Apiaí & - & -24.50 & -48.84 & $\begin{array}{l}\text { Curcio et al. } \\
\qquad(2012)\end{array}$ \\
\hline São Paulo & Barueri & - & -23.51 & -46.88 & $\begin{array}{l}\text { Curcio et al. } \\
\qquad(2012)\end{array}$ \\
\hline São Paulo & Biritiba Mirim & - & -23.57 & -46.03 & $\begin{array}{l}\text { Curcio et al. } \\
\qquad(2012)\end{array}$ \\
\hline São Paulo & Juquitiba & - & -23.93 & -47.06 & $\begin{array}{l}\text { Curcio et al. } \\
\qquad(2012)\end{array}$ \\
\hline São Paulo & Salesópolis & $\begin{array}{c}\text { Estação Biológica de } \\
\text { Boracéia }\end{array}$ & -23.65 & -45.9 & $\begin{array}{l}\text { Curcio et al. } \\
\qquad(2012)\end{array}$ \\
\hline São Paulo & Santo Amaro & Serra de Paranapiacaba & -23.710 & -46.768 & Amaral (1930) \\
\hline São Paulo & Santo André & $\begin{array}{c}\text { Estação Ferroviária } \\
\text { Campo Grande }\end{array}$ & -23.759 & -46.374 & $\begin{array}{l}\text { Curcio et al. } \\
\qquad(2012)\end{array}$ \\
\hline São Paulo & $\begin{array}{l}\text { Santo Antônio do } \\
\text { Pinhal }\end{array}$ & - & -22.82 & -45.66 & $\begin{array}{l}\text { Curcio et al. } \\
\qquad \text { (2012) }\end{array}$ \\
\hline São Paulo & $\begin{array}{l}\text { Santo Antônio do } \\
\text { Pinhal }\end{array}$ & $\begin{array}{c}\text { Estação Ferroviária } \\
\text { Eugênio Lefévre }\end{array}$ & -22.825 & -45.629 & $\begin{array}{l}\text { Curcio et al. } \\
\qquad(2012)\end{array}$ \\
\hline São Paulo & São Miguel Arcanjo & $\begin{array}{c}\text { Parque Estadual Carlos } \\
\text { Botelho }\end{array}$ & -23.878 & -47.997 & $\begin{array}{l}\text { Forlani et al. } \\
\qquad(2010)\end{array}$ \\
\hline São Paulo & São Miguel Arcanjo & $\begin{array}{c}\text { Parque Estadual Carlos } \\
\text { Botelho }\end{array}$ & -24.063 & -47.995 & $\begin{array}{l}\text { Forlani et al. } \\
\qquad(2010)\end{array}$ \\
\hline São Paulo & São Paulo & - & -23.56 & -46.62 & $\begin{array}{l}\text { Curcio et al. } \\
\qquad(2012)\end{array}$ \\
\hline São Paulo & Tapiraí & - & -23.96 & -47.50 & $\begin{array}{l}\text { Curcio et al. } \\
\qquad(2012)\end{array}$ \\
\hline São Paulo & Ubatuba & $\begin{array}{l}\text { Projeto Dacnis } \\
\text { Private Reserve }\end{array}$ & -23.4573 & -45.1462 & $\begin{array}{c}\text { Tanaka et al. } \\
\text { (2018) }\end{array}$ \\
\hline Paraná & $\begin{array}{c}\text { Campina Grande do } \\
\text { Sul }\end{array}$ & Capivari River & -24.989 & -48.593 & $\begin{array}{l}\text { Capela et al. } \\
\text { (2017) }\end{array}$ \\
\hline
\end{tabular}


the closest known localities. In addition, the new record fills a distributional gap of T. paucisquamis in southeastern Brazil, and reinforces the hypothesis that the Serra da Mantiqueira may represent the western border of its geographic range (Curcio et al. 2012). Lastly, it reveals the presence of T. paucisquamis at a protected area in Minas Gerais, the Serra do Brigadeiro State Park, considered a priority area for the conservation of the herpetofauna of Minas Gerais (Drummond et al. 2005). The occurrence of T. paucisquamis at PESB increases the park's known reptile richness (Moura et al. 2012) to 41 species.

So far, we found records of this species in 26 localities and about 50 specimens are deposited in scientific collections (e.g., Curcio et al. 2012, Capela et al. 2017, Tanaka et al. 2018). Although our understanding of the geographic distribution of $T$. paucisquamis has increased, it is pivotal that more studies are conducted in order to understand more about the biology and natural history of this rare species. Despite that the Atlantic Forest is the most studied Brazilian biome (Oliveira et al. 2016), with many scientific collections, it still lacks information to provide a better understanding of the patterns of diversity and distribution of many reptile species (Bérnils et al. 2009). This lack of data and herpetofaunistic inventories may be responsible for the previous distribution pattern observed for this snake, especially in the state of Minas Gerais when compared to the states of São Paulo and Rio de Janeiro, which have large and traditional reference centers in faunistic studies, such as the Instituto Butantan and the Museu Nacional, respectively. Another factor that must be considered is that the elevation can be a determining factor in the distribution of this species. As suggested by Moura et al. (2017), in the Atlantic forest, topographic complexity works as a climatic barrier that precludes the dispersion of the species.

In addition, the extinction risk of T. paucisquamis is currently unassessed globally (IUCN 2017), nationally (MMA 2014), and regionally (COPAM 2010), which is mostly associated with the rarity of this species, both in nature and scientific collections. Considering the current anthropogenic pressure in the Brazilian Atlantic Forest (Myers et al. 2000), T. paucisquamis is likely to be endangered. Thus, we hope that this study provides information that contributes to determine the current status risk of T. paucisquamis, its distribution and to design strategies for the conservation of the species.

\section{ACKNOWLEDGMENTS}

We would like to thank Sr. Francisco Inácio "Chiquinho", who assisted us in the logistics of the expedition. We also thank the Amphibians of Mantiqueira Project: "Biogeography and Amphibian Conservation in the Mantiqueira Mountain Complex, Southeastern Brazil" (CNPq - 458467/2014-6) for the financial grant. We are grateful to Dr. Felipe Polivanov Ottoni and anonymous reviewers. Finally, we thank Jhonny Guedes, Clodoaldo Assis and Henrique Costa for the contributions.

\section{REFERENCES}

Amaral, A. 1930. A rare Brazilian snake. Butantan São Paulo, 4(1), 13-16.

Antunes, A. P., \& Haddad, C. F. B. 2009. Tropidophis paucisquamis (Brazilian Dwarf Boa). Diet and caudal luring. Herpetological Review, 40(1), 104.

Barbo, R. V., Marques O. A. V., \& Sawaya, R. J. 2011. Diversity, natural history, and distribution of snakes in the municipality of São Paulo. South American Journal of Herpetology, 6(3), 135-160. DOI: 10.2994/057.006.0301

Bérnils, R. S., Nogueira, C. C., \& Xavier-da-Silva, V. 2009. Répteis. In: G. M. Drummond, C. S. Martins, M. B. Greco, \& F. Vieira (Orgs.), Biota Minas: Diagnóstico do conhecimento sobre a biodiversidade no Estado de Minas Gerais Subsídio ao Programa BIOTA MINAS. pp. 251278. Belo Horizonte: Fundação Biodiversitas.

Capela, D. J. V., Morato, S. A. A., Moura-Leite, J. C., Prado, F., Borges, G. O., \& Camilo, L. H. A. 2017. Tropidophis paucisquamis (Müller in Schenkel, 1901) (Serpentes, Tropidophiidae): first record from Paraná state and southern Brazil. Check List, 13(6), 917-920. DOI: 10.15560/13.6.917

Carvalho, A. L. 1951. Observações sôbre "Tropidophis paucisquamis" (Muller, 1901). Revista Brasileira Biologia, 11(3), 239-248.

COPAM - Conselho Estadual de Política Ambiental. 2010. Deliberação Normativa COPAM no 147 , de 30 de abril de 2010: Aprova a Lista de Espécies Ameaçadas de Extinção da Fauna do Estado de Minas Gerais. Minas Gerais (Diário do 
Executivo), Retrieved on 04 May, 2010.

Curcio, F. F., Sales Nunes, P. M., Argolo, A. J. S., Skuk, G., \& Rodrigues, M. T. 2012. Taxonomy of the South American Dwarf Boas of the Genus Tropidophis Bibron, 1840, with the description of two new species from the Atlantic Forest (Serpentes: Tropidophiidae). Herpetological Monographs, 26(1), 80-121. DOI: 10.1655/ HERPMONOGRAPHS-D-10-00008.1

Drummond, G. M., Martins, C. S., Machado, A. M., Sebaio, F. A., \& Antonini, Y. O. 2005. Biodiversidade em Minas Gerais: um atlas para sua conservação. Belo Horizonte: Fundação Biodiversitas.

Forlani, M. C., Bernardo, P. H., Haddad, C. B. F, \& Zaher, H. 2010. Herpetofauna of the Carlos Botelho State Park, São Paulo State, Brazil. Biota Neotropica, 10(3), 265-309. DOI: 10.1590/ S167606032010000300028

Freitas, M. A. 2003. Serpentes Brasileiras. Lauro de Freitas: Malha-de-sapo Publicações: p. 33. Retrieved from https://ww2.ibge.gov.br/home/ presidencia/noticias/21052004biomashtml. shtm

Hedges, S. B. 2002. Morphological variation and the definition of species in the snake genus Tropidophis (Serpentes, Tropidophiidae). Bulletin of the Natural History Museum: Zoology Series, 68(2), 83-90. DOI: 10.1017/ S0968047002000092

IBGE \& MMA. Mapa de Biomas do Brasil 1: 5.000.000. 2004. Retrieved on 20 May, 2018,

IUCN. 2017. The IUCN Red List of Threatened Species, version 2017-3.

Levandeira-Gonçalves, M. A. P., Aguiar, F. V. O., Camargo, J.V. C., Barros-Filho, J. D., \& Carvalho-e Silva, S. P. 2007. Levantamento preliminar da fauna de répteis do Parque Nacional da Serra dos Órgãos. In: C. Cronemberger \& E. B. Viveiros de Castro (Orgs.), Ciência e conservação na Serra dos Órgãos. pp. 138-153. Brasília, DF: Instituto Chico Mendes de Conservação da Biodiversidade.

MMA - Ministério do Meio Ambiente. 2014. Portaria no 444, de 17 de dezembro de 2014: Reconhece como espécies da fauna brasileira ameaçadas de extinção aquelas constantes da "Lista Nacional Oficial de Espécies da Fauna Ameaçadas de Extinção" - Lista,conforme Anexo I da presente Portaria, em observância aos arts. 60 e 7o, da
Portaria ${ }^{\circ} 43$, de 31 de janeiro de 2014. Diário Oficial da União, 245, 121-126.

Moura, M. R., Argôlo, A. J., \& Costa, H. C. 2017. Historical and contemporary correlates of snake biogeographical subregions in the Atlantic Forest hotspot. Journal of Biogeography, 44(3), 640-650. DOI: $10.1111 /$ jbi.12900

Moura, M. R., Motta, A. P., Fernandes, V. D., \& Feio, R. N. 2012. Herpetofauna da Serra do Brigadeiro, um remanescente de Mata Atlântica em Minas Gerais, sudeste do Brasil. Biota Neotropica, 12(1), 1-27. DOI: DOI: 10.1590/S167606032012000100017

Myers, N., Mittermeier, R. A., Mittermeier, C. G., Fonseca, G. A., \& Kent, J. 2000. Biodiversity hotspots for conservation priorities. Nature, 403(6772), 853. DOI: DOI: $10.1038 / 35002501$

Oliveira, U., Paglia, A. P., Brescovit, A. D., de Carvalho, C. J., Silva, D. P., Rezende, D. T., Leite, F. S. F., Batista, J. A. N., Barbosa, J. P. P. P., Stehmann, J. R., Ascher, J. S., Vasconcelos, M. F., MarcoJunior, P., Lowenberg-Neto, P., Dias, P. G., Ferro, V. G., \& Santos, A. J. 2016. The strong influence of collection bias on biodiversity knowledge shortfalls of Brazilian terrestrial biodiversity. Diversity and Distributions, 22(12), 1232-1244. DOI: $10.1111 /$ ddi. 12489 .

Salles, R. D. O. L., \& Silva-Soares, T. 2010. Répteis do município de Duque de Caxias, Baixada Fluminense, Rio de Janeiro, Sudeste do Brasil. Biotemas, 23(2), 135-144. DOI: 10.5007/2175-7925.2010v23n2p135

Tanaka, R. M., Rotenberg, E. L., \& Muscat, E. 2018. Tropidophis paucisquamis Müller, 1901 (Reptilia, Squamata, Tropidophiidae): a reliable record for lowland Atlantic Forest in Ubatuba, São Paulo. Herpetology Notes, 11, 243-244.

Submitted: 19 November 2018 Accepted: 15 May 2019

Published online: 15 June 2019 Associate Editor: Felipe Polivanov Ottoni 